REPORTS OF MORPHOLOGY
Official Journal of the Scientific Society of Anatomists,
Histologists, Embryologists and Topographic Anatomists
of Ukraine
journal homepage: https://morphology-journal.com

\title{
Features of structural-morphological changes in cases of experimental intestinal antibiotic-induced dysbiosis
}

Bobyr V.V. ${ }^{1}$, Poniatovskyi V.A. ${ }^{1}$, Chobotar A.P. ${ }^{1}$, Stechenko L.O. ${ }^{1}$, Kryvosheyeva O.I. ${ }^{1}$, Nazarchuk O.A. ${ }^{2}$, Kovalenko O.0.1

${ }^{1}$ Bogomolets National Medical University Ministry of Health of Ukraine, Kyiv, Ukraine;

${ }^{2}$ National Pirogov Memorial Medical University, Vinnytsya, Ukraine

\section{ARTICLEINFO}

Received: 25 July, 2018

Accepted: 20 August, 2018

UDC: $616.34: 615.211 .099$

\section{CORRESPONDING AUTHOR}

e-mail: vitalibobyr@ukr.net Bobyr V.V.

\begin{abstract}
Nowadays, scientists often define dysbiosis as a condition of a microbial ecological system, in which there is a simultaneous abnormality of the functions and interaction mechanisms of its key components: macroorganism and indigenous microbiota associated with the mucous membranes of cavities and skin. At the same time, obviously, the basis of all these processes is changes of structural intestinal components that are caused by qualitative and quantitative changes in the normal microflora. Purpose: to study the ultrastructural organization of the mucous membrane of the small intestine of mice after the formation of dysbiosis of the intestine. Outbred white mice in the number of 40 units (20 - experimental and 20 control) was served as an experimental model. Antibacterial drugs (ampicillin, metronidazole and gentamicin) are used to form dysbiosis. The conducted experiments are allowed to establish that the using of antibacterial drugs in the above-mentioned doses contributes to shortening the length of the microvillus and their reduction (disappearance) in some places, destruction with subsequent disintegration. According to the results of electronograms analysis, the assumption was made about stimulating the secretory function of the small intestine enterocytes by powerful doses of antibacterial drugs. In addition, it was found that the formation of dysbiotic disorders is accompanied by a defect of the connection between epithelial cells due to the expansion of the intercellular space and the disappearance of the dense plate. Research results also indicate that antibiotics that were used in the experiment can cause development of apoptosis. In addition, it has been shown that, on the background of the dysbiotic disorders formation, the activation of immune processes is taking place, as evidenced by the appearance of a significant number of Paneth cells, plasma cells with enlarged tubules, apparently due to their filling with immunoglobulins, as well as the growth of numbers of luminalis eosinophils and basophils. The ability of antibiotics to form dysbiotic states with pronounced cytodestructive disorders in the epithelium of the small intestine with the development of apoptosis was substantiated; the argument about the immune stimulating effect of antibiotic induced dysbiosis is argued.

Keywords: antibiotics, dysbiosis, intestine, microbiota, electron microscopy.
\end{abstract}

\section{Introduction}

According to the latest data human intestine contains about 100 trillion bacteria, $70-80 \%$ of which today cannot be cultivated yet $[2,8,13]$. Nowadays, scientists often consider the intestinal microbiota as a kind of extracorporeal organ, which provides vital aspects of human vital activity [2, 6, 22, 23]. Every man is considered to have several hundred of bacterial species. Among them there are predominantly Gram-positive Firmicutes (first of all Clostridium, Enterococcus, Lactobacillus) and Gram-negative ones
Bacteroides. In general, the human microbe is characterized by pronounced multifunctional activity that provides the vital functions of the macroorganism. But, at the same time, according to scientists view the normal microflora differs and expressed susceptibility, and even, may be a kind of indicator of adverse effects on the body [25]. The composition of a normal microflora can be influenced by a number of factors such as inflammatory bowel disease, psychoemotional overload, unfavorable ecological picture, etc. [14, 
24]. However, the effect of chemotherapeutic drugs, especially with the oral mechanism of administration is thought among the prior ones. Earlier, a violation of the quantitative and qualitative composition of the normal intestinal microflora was called dysbiosis. Although, the term "dysbiosis", was proposed was proposed by A. Nissle in 1916, and was associated with fungal and fermentative intestinal dyspepsia, had been caused by a decrease in the concentration of the Escherichia coli in the intestine. For sure, this term does not correspond to modern postulates about the nature of violations in human microbiocenosis, because it is limited to the statement of changes exclusively to the bacterial component of the intestinal consortium [21].

Because of this, the term "dysbiosis" is more often used today. This one more in detail characterizes the microbial ecology and, in particular, indicates that in the case of dysbiosis disturbances, the ratio between different representatives of microbial world (bacteria, fungi, viruses, protozoa) changed, the latter is accompanied changes in their biological properties and mechanisms of interaction with macroorganism $[15,17]$.

Nowadays, scientists most often identify dysbiosis as a condition of a microbial ecological system, in which there is a simultaneous violation of the functions and mechanisms of interaction of its key components: macroorganism and indigenous microbiota associated with the mucous membranes of the cavities and skin [4, 11, 17].

At the same time, obviously, changes in the structural components of the intestine, which are caused by qualitative and quantitative changes of normobiota are the basis of all these processes. It is important that the intestinal microflora of a person does not differ much from the intestinal microflora of other mammals, which facilitates the methodology of its study. $[11,12]$.

The aim - to study the ultrastructural organization of the mucous membrane of the small intestine of mice after the formation of dysbiosis of the intestine.

\section{Materials and methods}

As experimental model there were used 40 laboratory white mice (20 - experimental and 20 - control ones). These animals were kept in accordance with "Standard rules on the ordering, equipping and maintenance of experimental biological clinics (vivarium)". All animal experiments complied with the ARRIVE guidelines and were carried out in accordance with the general ethical principles of experiments on animals, adopted by the First National Congress of Ukraine on Bioethics (Kyiv, 2001), Law of Ukraine No. 3447-IV of February 21, 2006 "On the Protection of Animals from Cruel Treatment" and associated guidelines, EU Directive 2010/63/EU for animal experiments, certified by the Ethics Commission of Bogomolets National Medical University (protocol No. 65 of October 3, 2012) [1].

For the formation of dysbiotic states there were used antibacterial drugs, daily doses of which were for ampicillin and metronidazole $10 \mathrm{mg}$, for gentamicin $2.9 \mathrm{mg}$ [3]. Animals were injected intragastrically using a tuberculin syringe with a needle with thickening at the end. Simultaneously with the drinking water, the specified antibiotics were added $(1 \mathrm{~g}$ of ampicillin, $1 \mathrm{~g}$ of metronidazole and $290 \mathrm{mg}$ of gentamicin per $1000 \mathrm{ml}$ of water). The selection of feces and the administration of antibiotic solutions to animals were repeated for 5 days, with a daily determination of the total number of fecal microflora and its individual representatives (Escherichia, Bifidobacteria, Lactobacilli).

The animals were killed on the six day of the experiment for the purpose of pathology section examination. For the electron microscopic examination small pieces of small intestine of $1 \mathrm{~mm} 3$ in size were prepared. The specimens of intestine were prior fixed with a buffer solution of glutaraldehyde fixation for 1 hour, and then, after washing with a buffer, they were finished with $1 \%$ osmium tetroxide solution for 1 hour.

After dehydration in ethanol of increasing concentration and acetone, the material was poured into a mixture of epoxy resins (epon and araldite) and polymerized at $+60^{\circ} \mathrm{C}$ for 36 hours. Cutting-up the samples were obtained using glass knives on ultra-microcrystal "LKB III, Sweden" and investigated in electron microscopes Jeol JEM 100 CX II (Japan) and PEM-125 (Ukraine). Before microscopy, the sections were contrasted with uranyl acetate and lead citrate according to the standard procedure $[9,20]$.

\section{Results}

The method used to simulate dysbiosis allowed us to obtain qualitative and quantitative disturbances in the composition of normal intestinal microflora of animals, which were confirmed bacteriologically. In a result of our experiments there was found that after the use of antibacterial drugs at the above doses, a visual shortening of the length of the microvilli was observed, and in places reduction (disappearance) or degradation with subsequent disintegration (Fig. 1, 2) compared with the control (Fig. 3). In this case, the total desquamation of microvilli was also often noted; in such cells, the brush border was absent, the plasma membrane

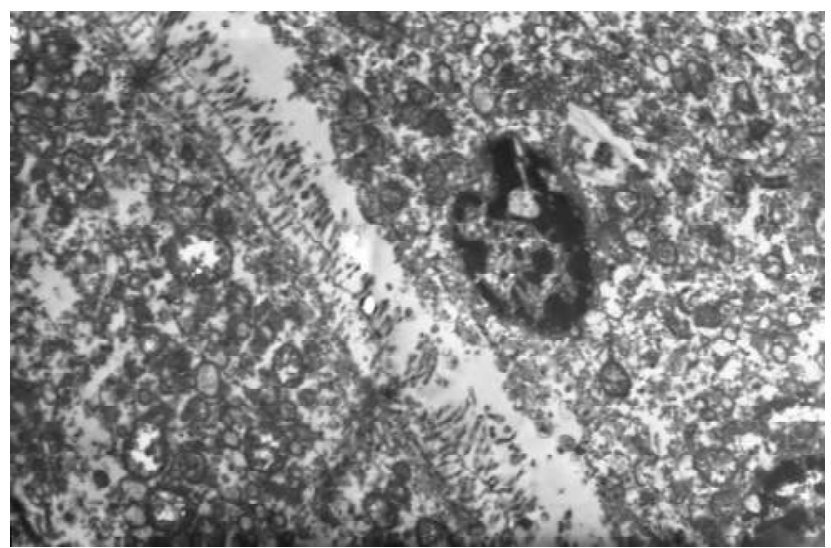

Fig. 1. Electronic microphotography. Local reduction of the brush border of enterocytes of the small intestine of the mouse with antibiotic induced dysbiosis. $\times 4200$. 


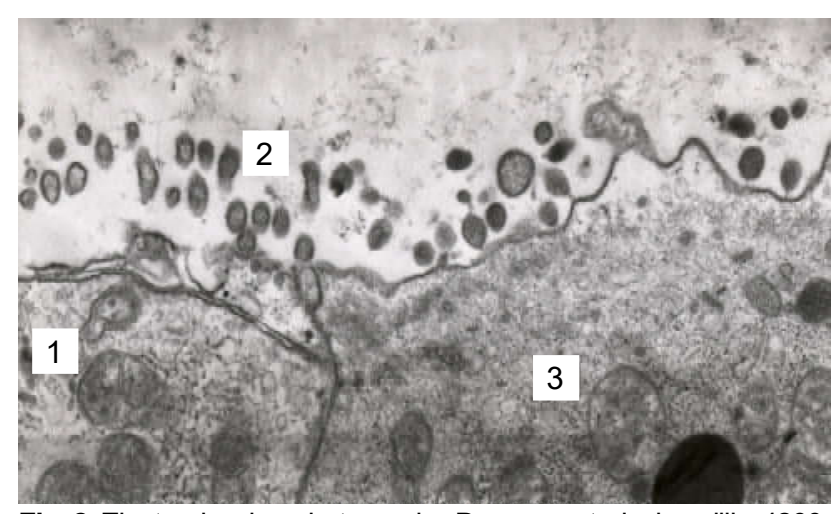

Fig. 2. Electronic microphotography. Desquamated microvilli. x4200. 1 - autophagosome; 2 - microvilli; 3 - mitochondria.

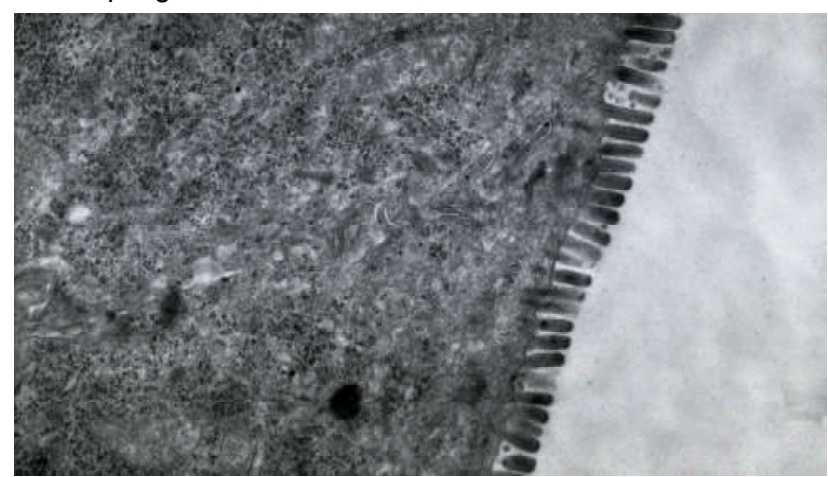

Fig. 3. Electronic microphotography. Brush border of enterocytes of the small intestine of the mouse. Control. $x 4200$.

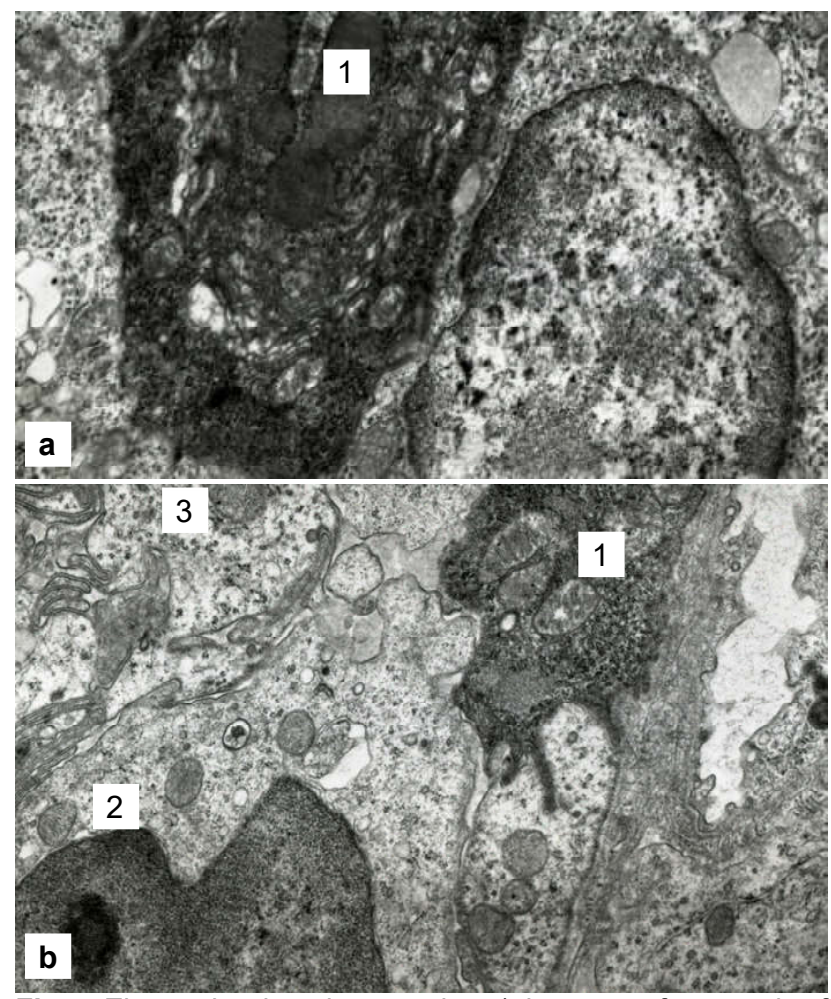

Fig. 4. Electronic microphotography: a) the onset of apoptosis of enterocytes of the small intestine (1); b) prolonged apoptosis of enterocytes of the small intestine. The death of enterocytes (1) lymphocytes between enterocytes (2); enterocytes (3). x4200.

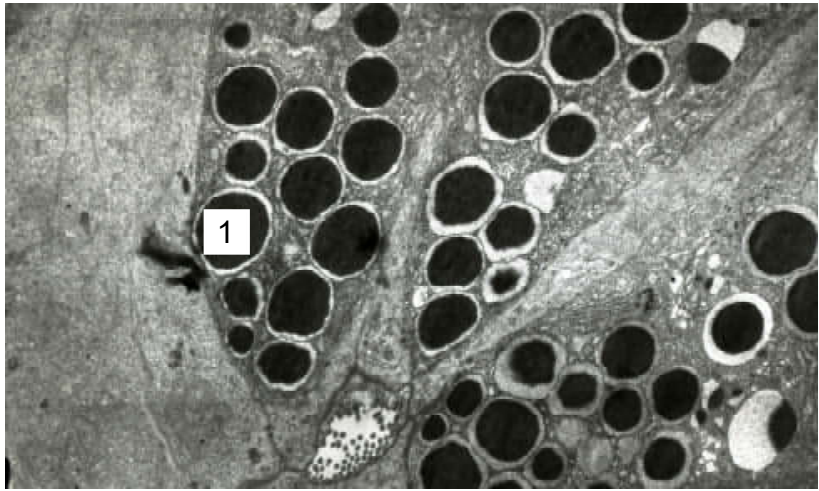

Fig. 5. Electronic microphotography. The accumulation of Paneth cells after the formation of dysbiosis. Paneth cell granules (1). x4200.

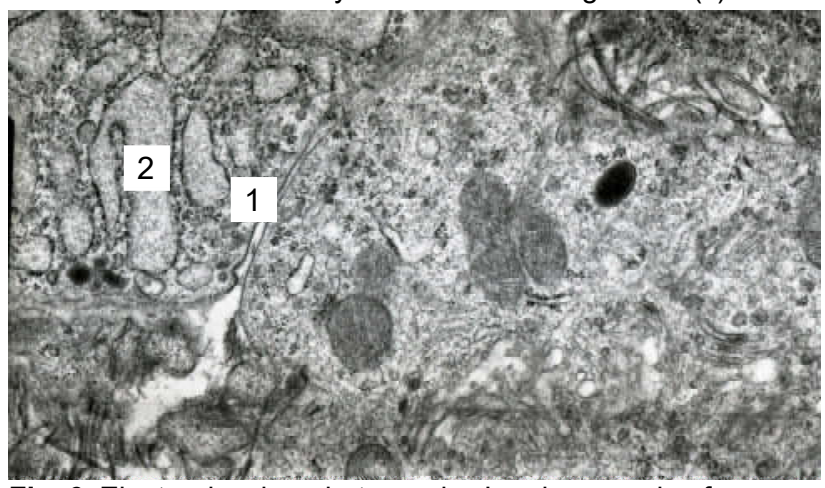

Fig. 6. Electronic microphotography. Lamina propria of mucous membrane. Plasmocytes (1). Expanded tubules of plasmocytes (2). $\times 4200$.

was smoothed, and in the enterocytes the edema of the mitochondria and the formation of autophagosoms were noted.

The clarification of the matrix of the cytoplasm, which indicated an insignificant edema was determined. At the same time, the locking lamina of the contacts was considerably thinned - as a result of which the expansion of contacts between the cells was observed.

We have found that the formation of dysbiotic disorders is accompanied by a violation of the relationship between epithelial cells due to the expansion of the intercellular space. The results of the studies also indicate the ability of the antibiotics, have been used in the experiment, to induce apoptosis: the cells were displaced to the basement membrane, they were densified, especially in the cytoplasm, there were no nuclei already visualized in electronogram, all organelles and predecessors of apoptosis were condensed and displaced to the basement membrane with subsequent exclusion from a number of epithelial cells (Figures 4a-b). The conducted experiments also allowed to establish, that activation of immune processes took place against the background of the formation of dysbiotic disorders, as evidenced by the appearance of a significant number of Paneth cells (Fig. 5). A significant response from the immune system was also proved by the presence of a significant number of plasma cells. In some electronic microphotographs, the expansion of the tubule cells of the plasma 


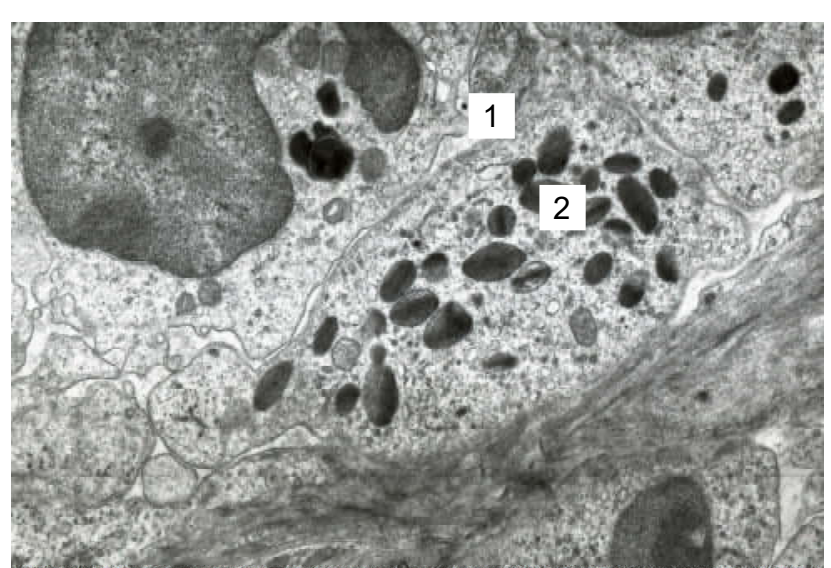

Fig. 7. Electronic microphotography. Eosinophil in the lumen of the capillary (1) with characteristic longitudinal beads with core (2). $x 4200$.

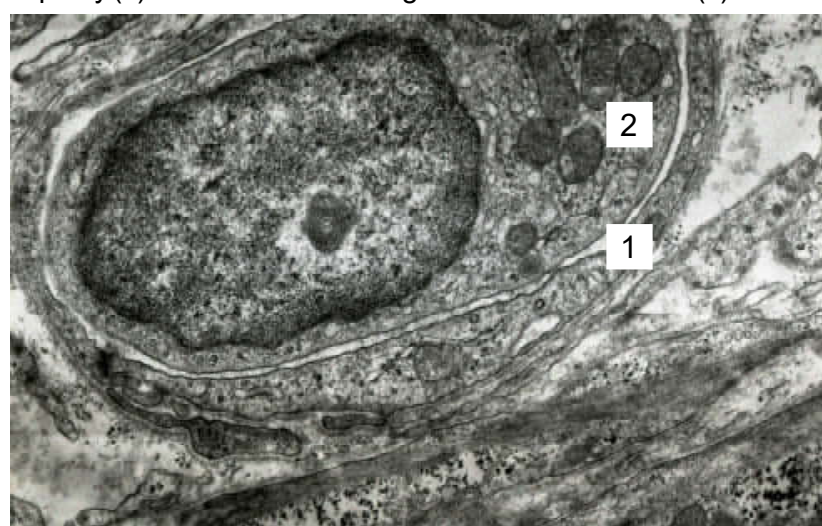

Fig. 8. Electronic microphotography. Lamina propria of the mucous membrane of the small intestine. Enlightenment of the capillary (1), which contains B-lymphocyte (2). x4200.

cells was clearly traceable, apparently due to their filling with immunoglobulins (Fig. 6). In addition, the analysis of electronic microphotographs showed that in the case of antibiotic induced dysbiosis, the number of educational eosinophils and basophils increased (Fig. 7).

These cells were like indicators of allergic reactions because of their direct involvement in the protective allergic and anaphylactic reactions of the body. An increase in the number of B-lymphocytes between enterocytes and in the lumen of capillaries was evidenced by the formation of the immune response (Fig. 8).

\section{Discussion}

Normal microflora of the human body is represented by an extraordinary qualitative and quantitative diversity of microorganisms. The microbiota of the intestine, as one of the most numerous biotops in the body, is the consortium of microorganisms, been very sensitive to many factors $[2,7$, $10,23]$. There is an assumption that dysbiosis, or a violation of the quantitative and qualitative composition of the normal intestinal microflora, leads to violations of the microbial ecological system, functions, mechanisms of interaction of the macroorganism and indigenous microbiota, and changes in the structural components of the intestine. The scientific interest is the in-depth study of the ultrastructural organization of the mucous membrane of the small intestine under conditions of dysbiotic changes [4, 16].

According to the data of bacteriological analysis there was proved, that modeling of dysbiosis allowed to obtain qualitative and quantitative violations of the composition of normal intestinal microflora of experimental animals. Obviously, the oral administration of antibacterial drugs can contribute to the development of functional disorders in the intestine, which are already manifested at the ultrastructure level. According to the researchers' reports the effect of dysbiotic disturbances on the suction and secretory activity of the small intestine with destructive changes in columnar enterocytes with a rim was known [18]. The cytoplasmic matrix, which was registered in the study, showed a slight edema. At the same time, there was observed the considerably thinned locking lamina gut, that resulted in the expansion of the contacts between the enterocytes.

According to a various studies, the ability of some drugs, including acetaminophen, has been shown to cause dysbiotic disturbances in animals. Electronic microscopy picture characterises these violations as one accompanied by structural changes in stem cells, namely, hypertrophy of mitochondria, which manifests itself as a clarification of the matrix and reduction of crypt [5]. In the formation of antibiotic induced dysbiosis in mice such changes were not registered. The formation of dysbiotic disorders was established to be accompanied by a violation of the relationship between epithelial cells due to the expansion of the intercellular space. In our study, the emergence of a significant number of Paneth cells in the background of the formation of dysbiotic violations was found to indicate the activation of immune processes. Recent studies have proved the important role of these cells in the regulation of intestinal homeostasis, and identified Paneth cells as an important component of the protective mechanisms of congenital immunity $[5,6]$.

The prospect of further research is the in-depth study of mechanisms stimulating the influence of antibiotic-induced dysbiosis on local immune reactivity.

\section{Conclusions}

1. The ability of antibacterial drugs to form dysbiotic states in animals accompanied by marked cytodestructive disorders in the small intestine epithelium, namely, the shortening and desquamation of microvilli, edema of mitochondria, cytoplasmic matrix enlightenment, the violation of the relationship between epithelial cells and the development of apoptosis, have been substantiated experimentally.

2. An argumentative assumption has been made about the stimulating effect of antibiotic induced dysbiosis on the activation of immune defense reactions. This has been confirmed by the growth in the number of Paneth cells, plasma cells filled with immunoglobulins, educational eosinophils and basophils, as well as an increase in the number of B-lymphocytes that are recorded between enterocytes and the lumen of the capillaries. 


\section{References}

[1] About protecting animals from abuse. (2006). The Law of Ukraine science 21.02.2006, № 3447-IV.

[2] Bilen, M., Dufour, J. C., Lagier, J. C., Cadoret, F., Daoud, Z., Dubourg, G., \& Raoult, D. (2018). The contribution of culturomics to the repertoire of isolated human bacterial and archaeal species. Microbiome, 6(1), 94. doi: 10.1186/s40168-0180485-5

[3] Bobyr, V. V., Ponyatovsky, V. A., Djugikowa, E. M., \& Shyrobokov V. P., (2015). Modeling of dysbiotic disorders with laboratory animals. Biomedical and Biosocial Anthropology, 24, 230233.

[4] Bron, P., Van Baarlen, P., \& Kleerebezem M. (2011). Emerging molecular in-sights into the interaction between probiotics and the host intestinal mucosa. Nat. Rev. Microbiol., 10, 66-78.

[5] Bykov, V. L., (2014). Paneth cells: history of discovery, structural and functional characteristics and the role in the maintenance of homeostasis in the small intestine. Morphology: Archives of anatomy, histology, and embryology, 145(1), 67-80.

[6] Chang, P. V., Hao, L., Offermanns, S., \& Medzhitov, R. (2014). The microbial metabolite butyrate regulates intestinal macrophage function via histone deacetylase inhibition. Proceedings of the National Academy of Sciences of the United States of America, 111(6), 2247-2252. doi: 10.1073/ pnas. 1322269111

[7] Dethlefsen, L., \& Relman, D. A. (2011). Incomplete recovery and individualized responses of the human distal gut microbiota to repeated antibiotic perturbation. Proc. Natl. Acad. Sci. USA, 108(1), 4554-4561. doi: 10.1073/pnas.1000087107

[8] Duvallet, C., Gibbons, S. M., Gurry, T., Irizarry, R. A., \&Alm, E. J. (2017). Meta-analysis of gut microbiome studies identifies disease-specific and shared responses. Nat. Commun., 8, 1-46. doi: 10.1038/s41467-017-01973-8

[9] Dykstra, M. J., \& Reuss, L. E. (2003). Biological electron microscopy: theory, techniques, and troubleshooting. Springer Science \& Business Media.

[10] Falcony, G., Joossens, M., Vieira-Silva, S., Wang, J., Darzi, Y., Faust, K., ... Raes, J. (2016). Population-level analysis of gut microbiome variation. Science, 352(6285), 560-564. doi: 10.1126/science.aad3503

[11] Johnson, C. D., \& Kudsk, K. A. (1999). Nutritional and intestinal mucosal immunity. Clin. Nutr., 18(6), 337-344. doi: https:// doi.org/10.1016/S0261-5614(99)80012-0

[12] Kravchuk, R. I., Sheybak, V. M., Zhmakin, A. I., Goretsky, M. V., \& Egorov, A. S. (2007). Characteristics of ultrastructural changes in the mucous membrane of the jejunum after acetaminophen-induced rats dysbacteriosis. Journal of Grodno State Medical University, 1, 106-109.

[13] Lagier, J. C., Edouard, S., Pagnier, I., Mediannikov, O., Drancourt,
M., \& Raoult, D. (2015). Current and past strategies for bacterial culture in clinical microbiology. Clinical microbiology reviews, 28(1), 208-236. doi: 10.1128/CMR.00110-14

[14] Lin, L., \& Zhang, J. (2017). Role of intestinal microbiota and metabolites on gut homeostasis and human diseases. BMC immunology, 18(1), 2. doi: 10.1186/s12865-016-0187-3.

[15] Lloyd-Price, J., Abu-Ali, G., \& Huttenhower, C. (2016). The healthy human microbiome. Genome Med., 8(1), 51. doi: 10.1186/s13073-016-0307-y

[16] Mokili, J. L., Rohwer, F., \& Dutilh, B. E. (2012). Metagenomics and future perspectives in virus discovery. Current Opinion in Virology, 2(1), 63-77. doi: 10.1016/j.coviro.2011.12.004

[17] Moore, H. C., Jacoby, P., Taylor, A., Harnett, G., Bowman, J., Riley, T. V., ... Lehmann, D. (2010). The interaction between respiratory viruses and pathogenic bacteria in the upper respiratory tract of asymptomatic Aboriginal and non-Aboriginal children. Pediatr. Infect. Dis. J., 29(6), 540-545. doi: 10.1097/ INF.0b013e3181d067cb

[18] Ovcharova, A. N. (2012). The morphological characteristics of the small and large intestine in experimental primary dysbiosis and its correction by probiotics. (Abstract dis. Cand. Biol. Sciences). Scientific research Institute of Human Morphology, Moscow, RAMS.

[19] Qin, J., Li, R., Raes, J., Arumugam, M., Burgdorf, K. S., Manichanh, C. ... Wang, J. (2010). A human gut microbial gene catalogue established by metagenomic sequencing. Nature, 464, 59-65. doi: 10.1038/nature08821

[20] Sarkisova, D. S., \& Perova, Yu. L. (Edit.) (1996). Microscopic technique. Guide for doctors and laboratory technicians. Moscow: Medicine.

[21] Shirobokov, V. P., Yankovsky, D. S., \& Dyment, G. S. (2014). Microbes in biogeochemical processes, the evolution of the biosphere and the existence of mankind. K.: Veres.

[22] The Human Microbiome Project Consortium (2012). A framework for human microbiome research. Nature, 486(7402), 215-221. doi: 10.1038/nature11209

[23] Thursby, E., \& Juge, N. (2017). Introduction to the human gut microbiota. The Biochemical journal, 474(11), 1823-1836. doi: 10.1042/BCJ20160510

[24] Williams, M. D., Ha, C. Y., \& Ciorba, M. A. (2010). Probiotics as therapy in gastroenterology: A study of physician opinions and recommendations. J. Clin. Gastroenterol, 44(9), 631636. doi: 10.1097/MCG.0b013e3181d47f5b

[25] Yankovsky, D. S., Shirobokov, V. P., Volosovets, A. P., \& Moiseenko, R. A., Dyment, G. S. (2013). Human microbiome and modern methods of its improvement. Journal of the National Academy of Medical Sciences of Ukraine, 19(4), 411-420.

\section{ОСОБЛИВОСТІ СТРУКТУРНО-МОРФОЛОГІЧНИХ ЗМІН ПРИ ЕКСПЕРИМЕНТАЛЬНОМУ АНТИБІОТИКОІНДУКОВАНОМУ ДИСБІОЗІ КИШКІВНИКА \\ Бобир В.В., Понятовський В.А., Чоботар А.П., Стеченко Л.О., Кривошеєва О.І., Назарчук О.А., Коваленко О.О.} Сьогодні вчені найчастіше визначають дисбіози як такий стан мікробної екологічної системи, при якому спостерігається одночасне порушення фрункцій та механізмів взаємодії їі ключових компонентів: макроорганізму та індигенної мікробіоти, асоційованої зі слизовими оболонками порожнин та шкірних покривів. Разом із тим, очевидно, в основі всіх цих процесів лежать зміни структурних компонентів кишківника, які викликані якісними та кількісними змінами нормофолори. Мета роботи - вивчити ультраструктурну організацію слизової оболонки тонкої кишки мишей після фрормування дисбіотичних станів кишківника. Експериментальною моделлю слугували безпородні білі миші у кількості 40 одиниць (20 дослідних та 20 контрольних). Для фрормування дисбіотичних станів використано антибактеріальні препарати (ампіцилін, метронідазол та гентаміцин). Проведені експерименти дозволили встановити, що використання антибактеріальних препаратів у вищезазначених дозах сприяє вкороченню довжини мікроворсинок та місиями їх редукції (зникнення), деструкції із подальщим розпадом. За результатами аналізу електронограм зроблено припущення про стимуляцію секреторної фуннції ентероцитів 
тонкої кишки потужними дозами антибактеріальних препаратів. Встановлено, що формування дисбіотичних порушень супроводжується порушенням зв'язку між епітеліальними клітинами за рахунок розширення міжклітинного простору $i$ зникненням щільної пластинки. Результати досліджень також свідчать про здатність використаних в експерименті антибіотиків викликати розвиток апоптозу. Показано, що на фоні фоормування дисбіотичних порушень відбувається активізація імунних процесів, про що свідчить поява значної кількості клітин Панета, плазматичних клітин з розширеними канальцями, очевидно, за рахунок їх наповнення імуноглобулінами, а також зростання кількості просвітних еозинофрілів $i$ базофрілів. Таким чином, обгрунтована здатність антибіотиків формувати дисбіотичні стани з вираженими цитодеструктивними порушеннями в епітелії тонкої кишки з розвитком апоптозу; аргументовано припущення про імуностимулюючий вплив антибіотикоіндукованого дисбіозу.

Ключові слова: антибіотики, дисбіоз, кишківник, мікробіота, електронно-мікроскопічне дослідження.

\section{ОСОБЕННОСТИ СТРУКТУРНО-МОРФОЛОГИЧЕСКИХ ИЗМЕНЕНИЙ ПРИ ЭКСПЕРИМЕНТАЛЬНОМ АНТИБИОТИКОИНДУЦИРОВАННОМ ДИСБИОЗЕ КИШЕЧНИКА}

Бобирь В.В., Понятовский В.А., Чоботар А.П., Стеченко Л.А., Кривошеева О.И., Назарчук А.А., Коваленко А.О.

Сегодня ученые чаще всего определяют дисбиозы как такое состояние микробной экологической системы, при котором наблюдается одновременное нарушение функций и механизмов взаимодействия ее ключевых компонентов: макроорганизма и индигенной микробиоты, ассоциированной со слизистыми оболочками полостей и кожных покровов. Вместе с тем, очевидно, в основе всех этих процессов лежат изменения структурных компонентов кишечника, вызванные качественными и количественными изменениями нормофрлоры. Цель работы - изучить ультраструктурную организацию слизистой оболочки тонкой кишки мышей после формирования дисбиотических состояний кишечника. Экспериментальной моделью служили беспородные белые мыши в количестве 40 единиц (20 исследовательских и 20 контрольных). Для фоормирования дисбиотических состояний использованы антибактериальные препараты (ампициллин, метронидазол и гентамицин). Проведенные эксперименты позволили установить, что использование антибактериальных препаратов в вышеуказанных дозах способствует укорочению длины микроворсинок и местами их редукции (исчезновению), деструкции с последующим распадом. По результатам анализа электроннных микрофотографий сделано предположение о стимуляции секреторной фрункции энтероцитов тонкого кишечника мощными дозами антибактериальных препаратов. Кроме того, установлено, что формирование дисбиотических нарушений сопровождается нарушением связи между эпителиальными клетками за счет расширения межклеточного пространства и исчезновением плотной пластинки. Результаты исследований также свидетельствуют о способности использованных в эксперименте антибиотиков вызвать развитие апоптоза. Показано, что на фоне формирования дисбиотических нарушений происходит активация иммунных процессов, о чем свидетельствует появление значительного количества клеток Панета, плазматических клеток с расширенными канальцами, очевидно, за счет их наполнения иммуноглобулинами, а также увеличение количества просветительных эозинофилов и базофрилов. Таким образом, обоснована способность антибиотиков формировать дисбиотические состояния с выраженными цитодеструктивными нарушениями в эпителии тонкого кишечника с развитием апоптоза; аргументировано предположение об иммуностимулирующем влиянии антибиотик-индуцированного дисбиоза.

Ключевые слова: антибиотики, дисбиоз, кишечник, микробиота, электронно-микроскопическое исследование. 